\title{
Building Information Modeling Concept And Its Application in Building Renovation Stage In Term of Time Efficiency
}

\author{
Ardhiana Muhsin Machdi \\ ${ }^{1}$ Department of Architecture, Institut Teknologi Nasional, Bandung, Indonesia \\ 1 JIn. P.H.H. Musthopa No. 23 Bandung 40124, Indonesia \\ Corresponding Author: dade@itenas.ac.id \\ Article History: \\ Received: 10 Oktober Revised: 18 November Accepted: 10 Desember Available online: 31 Desember \\ $\begin{array}{llll}2019 & 2019 & 2019 & 2019\end{array}$
}

\begin{abstract}
Nowadays Building Information Modeling, known as BIM has become a common topic in construction technology. Indonesian government has even accelerated the implementation of BIM as a requirement in planning above $2000 \mathrm{~m} 2$ since year 2018. The word renovation in BIM life cycle means one of the post-project building phases after maintenance, rehabilitation but before reach demolition phases as an ending of the building. On the other hand, renovation is not a strange thing for the Indonesian people and has direct meaning to its activity. Even though occupying a new property, there is always a tendency to change, add or even reduce some parts of existing buildings. Renovation is also unavoidable when there is a change in function in a building and it can be classified as adaptive reuse as part of the concept of sustainable building, a preservation and rehabilitation of an old building that has unique design or contains certain historical significance. This research is structured and focuses more on the issue of time efficiency which is very significant in the renovation stage. The method used in the form of a comparison between conventional methods with methods that apply the BIM concept. This is interesting to be observed as the benefits of research so that the concept of BIM can be understood and seen its real advantages.
\end{abstract}

Keyword: building information modeling, renovation, efficiency

\section{Introduction}

Indonesia as a developing country needs to show it achievement in the field of construction as one of a tangible manifestation of its development. Architects and contractors are required to be always adaptive to technological developments so that the work handled is not only fast in completion but also careful and efficient. In Indonesia, ranging in 1996 or even a few years before the drawing method as a project document began to shift from the conventional hand drawing into a digital form of drawing with a two-dimensional (2D) Computer Aided Design (CAD). Aside from getting accurate drawings, another advantage of using CAD is library storage in the software which can be reused in subsequent drawings. This library is not just a single object but can be developed into small units such as shop houses, hotel rooms, apartments, hospitals and other functions that have similarities in the unit module.

As presentation material, visualization certainly plays a more important role in making it easier for the client to understand designer ideas than 2D drawings which are more technical. The threedimensional (3D) visualization technique that has been done conventionally also began to involve some software which is quite complicated if done without good coordination. It is often to find a mismatch between 3D images and 2D drawings. Some software then emerged offering other solutions to overcome these problems. Of course it is not enough just to simplify the drawing process but it is then developed with additional information from the resulting 3D model and technical drawings that can be obtained directly. This process came to be known as Building Information Modeling or BIM. At that time, not many construction players were interested in making changes back to the work method using 2D CAD. According to Berlian, Cinthia Ayu, dkk. (2016) the refusal is due to the need to re- 
invest in the device and assume the existing device is sufficient to complete the task or problem (Berlian, Cinthia Ayu, dkk. 2016). This study refers to two renovation cases, interviews with members of NFN Studio, a group of progressive young architects who began involving BIM in their projects and 30 respondents of architecture students who were willing to fill out questionnaires about BIM.

\section{Method}

\section{a. Research Chronological}

The stages of this research could describe as follows:

- Study and collect information from two renovation cases, especially on the method of presenting building drawing for renovation purposes.

- Interview with NFN Studio members in handling renovation cases.

- Collection of information through the BIM questionnaire with 30 architecture student respondents about BIM and renovation.

- Analysis and comparison of each stage in each workflow

- Conclusions

\section{b. Analysis Technique}

The study uses descriptive research methods when observing each renovation workflow either conventionally or using the BIM concept. The next step to sharpen the analysis is using a comparative method by comparing each stage that the two processes go through.

\section{Results and Discussion}

What makes BIM looks powerful and popular? According to Hardin in Minawati, Retnp, dkk (2017) BIM is a revolutionary technology and process that has rapidly changed the perspective of how to understand building design, implementation and operation. Furthermore, Dace (2007) said BIM also has the ability to create interactive design concepts that represent the physical and tangible images of a building that allow designers to identify client needs and effectively provide solutions to client needs. In addition, Rayendra, Soemardi, Biemo, W. (2014) stated BIM provides the potential to model virtual information in a single model that offers visualization, collision detection, construction phases, and materials as well as model testing to be submitted from the design team (architects, surveyors, consulting engineers, etc.) to contractors and sub -contractor and then to the owner.

In renovation project, preparation of drawings before construction begins is slightly different from ordinary design that usually start from scratch. The drawing is not presented in the form of a direct design but it is necessary to attach a plan of the old building or existing building.

Based on a survey of 30 respondents, $92 \%$ chose the method of describing the existing floor plan first and then duplicated and changed the drawing plan according to the renovation or changes. The rest $8 \%$ chose to draw the final change of the renovation project and not necessary to draw the existing plan using computer. NFN Studio chooses to add a floor plan demolition drawing and followed by a new construction floor plan before displaying the changes. This is considered important for NFN Studio members to check the calculation of the volume of demolition work and the new construction work. All of the respondents and member of NFN Studio are use 2D CAD as their drawing tools and add images of the building after renovation by using other tool.

Each of two reference object study has different method while both of them draw using one of BIM authorized software. The first is a small renovation project with residential as its function. The drawing renovation process is not necessary and focus on final design with the existing plan shown in Fig. 1 while the changing plan is on Fig. 2. In this case, the condition is not too different if compare with drawing method using 2D CAD while BIM still take advantage in drawing coordination and generating volume of demolition and new building component. 


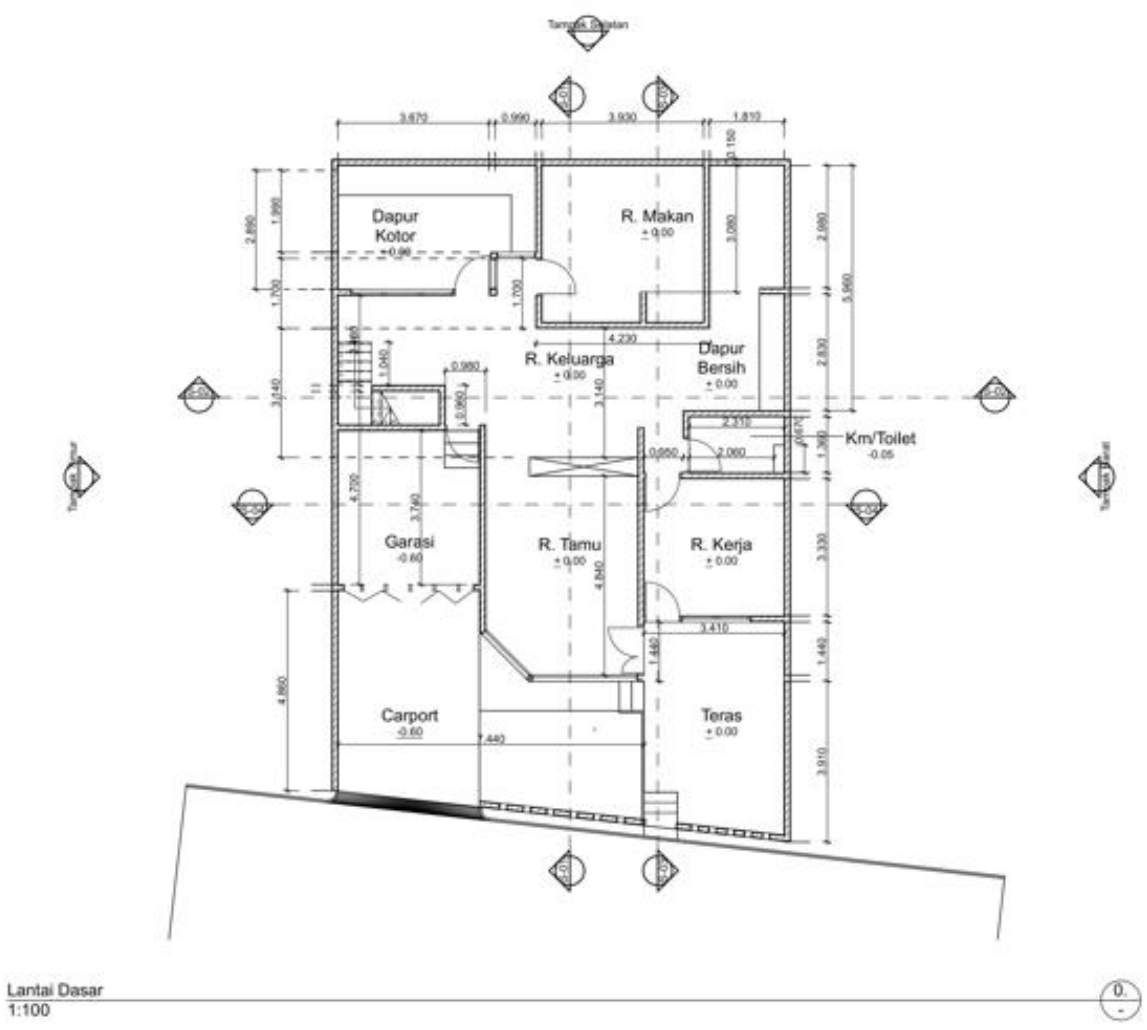

Figure 1. Existing Plan

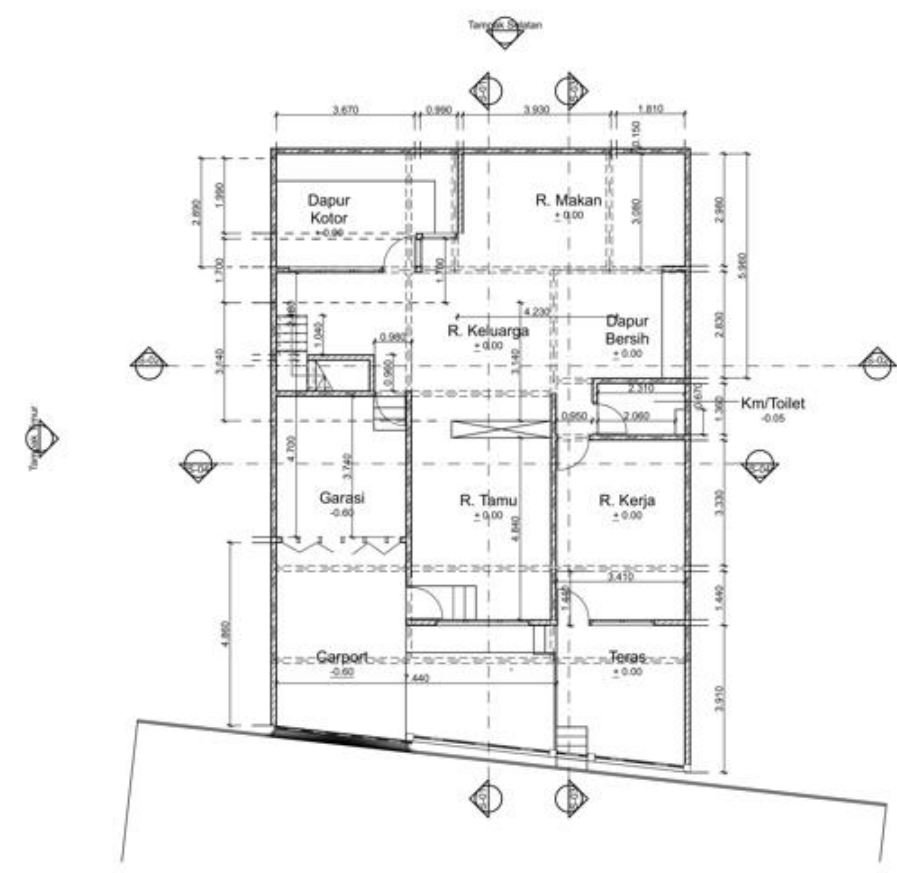

$\frac{\text { Lantai Dasar Pengembangan }}{1: 100}$

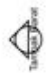

Figure 2. Renovation Plan

The second object study is a mosque as a public building. This mosque is manage by a foundation which has a number of stakeholder and funding by local community donation. Each phase of construction has to be careful and clear for all member of foundation before continuing to construction. That is why all the stakeholders are agree when purposing BIM as a tools in renovating 
the mosque. Base on Helander, David, and Singh (2016) the most important thing when creating models is that assumptions and levels of accuracy are well-documented in the model description document and marked in the model. In early design phase, the limitation of building document caused a collision between the new stairs and a beam on the second floor. The stairs finally decided move to the back part of the mosque.

The existing condition in 3D model is also important for public orientation. As seen in Fig. 3, the angel of the camera has chosen base on majority users when they came to the mosque. The demolition plan, see in Fig. 4, then presents with highlighting which part of the building that to be demolish with yellow color. It will show only with changing object classification properties from 'existing' to 'to be demolished' and follow with renovation filter by choosing 'Demolition Plan'.

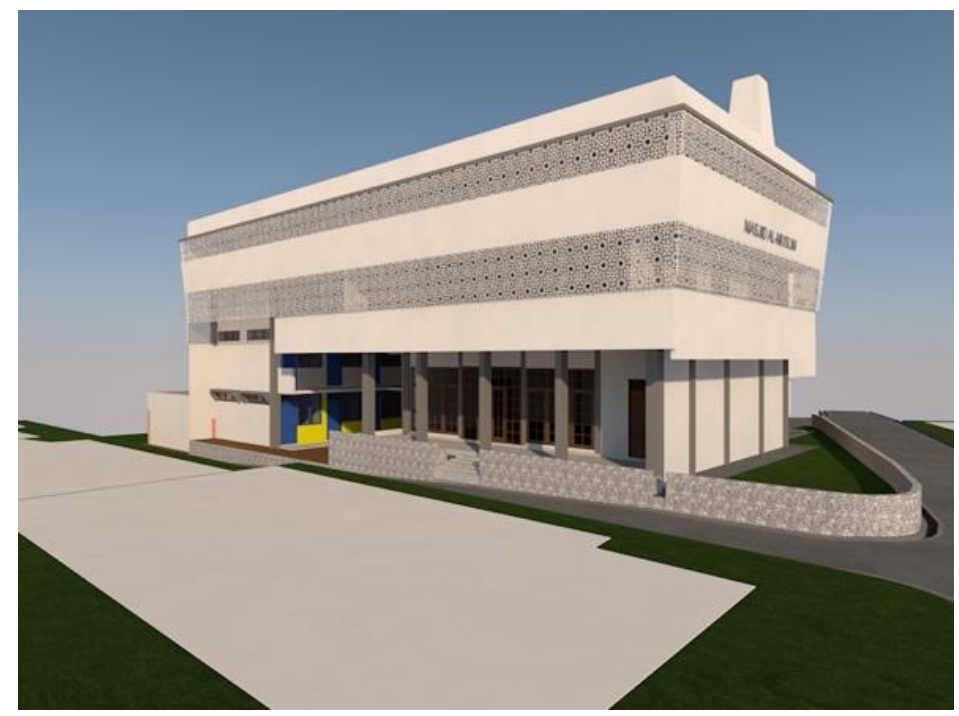

Figure 3. Existing Condition of the Mosque

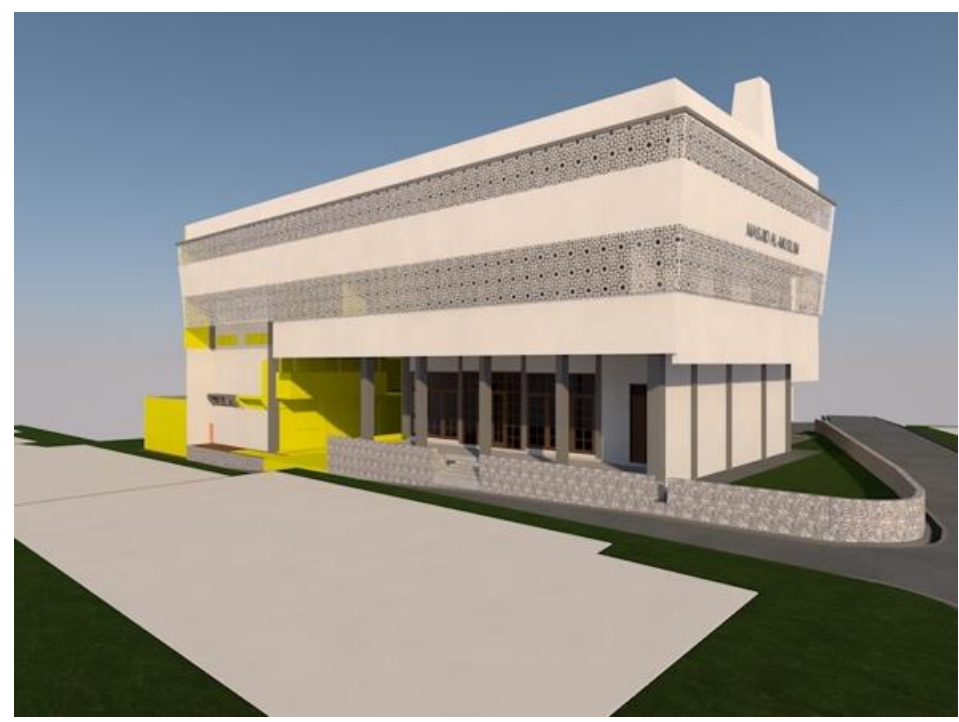

Figure 4. Demolition Plan (Highlited with Yellow)

The new construction to be applied is shown in Fig. 5 with a red mark. The same way with showing demolition plan, the new construction plan will show with changing object classification properties from 'existing' to 'new' and follow with renovation filter by choosing 'New Construction'. Finally, all of the final appearance of the building after renovation in Fig. 6 will show by changing to 'Planned Status'. 


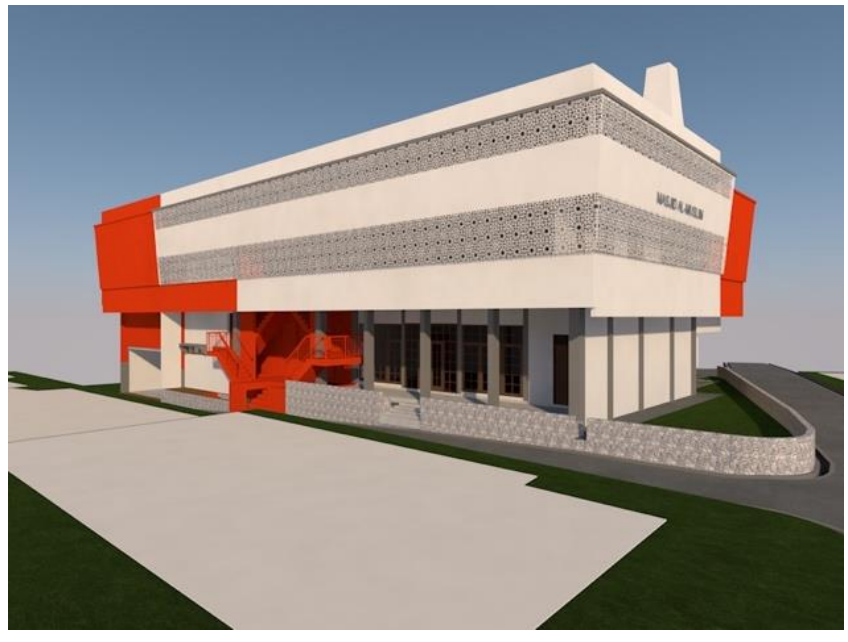

Figure 5. New Construction (Mark with Red Color)

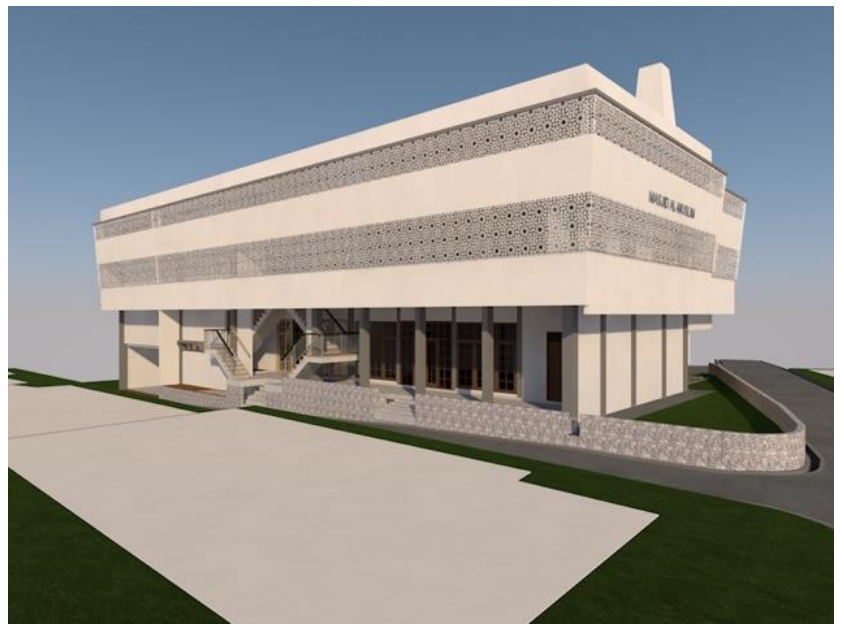

Figure 6. Final Appereance of the Mosque

A brief description of all the drawing process for renovation work either it was using $2 D C A D$ or using BIM can be seen in Table 1.

Tabel 1 Comparative Drawing Between CAD And BIM

\begin{tabular}{|c|c|c|c|}
\hline \multirow[b]{2}{*}{$\begin{array}{c}\text { Drawing } \\
\text { Tools }\end{array}$} & \multicolumn{3}{|c|}{ Process } \\
\hline & $\begin{array}{c}\text { Editing/ } \\
\text { Demolishin } \\
\text { g Command }\end{array}$ & $\begin{array}{c}\text { Adding New } \\
\text { Component } \\
\text { Command }\end{array}$ & $\begin{array}{c}\text { Settings/ } \\
\text { Enhancemen } \\
\text { ts }\end{array}$ \\
\hline CAD & Trim, Erase & $\begin{array}{l}\text { - Line, Polyline, } \\
\text { Rectangle, Arc, } \\
\text { Circle and other } \\
\text { drawing tools, } \\
\text { - Move, rotate, } \\
\text { mirror or } \\
\text { duplicate from } \\
\text { existing drawing }\end{array}$ & Hatch \\
\hline BIM & $\begin{array}{l}\text { Split, } \\
\text { Reshape or } \\
\text { Resize } \\
\text { Object, } \\
\text { Erase }\end{array}$ & $\begin{array}{l}\text { - Column, Beam, } \\
\text { Slab and others } \\
\text { building } \\
\text { component, } \\
\text { - Drag, rotate, } \\
\text { mirror or make a } \\
\text { copy from } \\
\text { existing drawing }\end{array}$ & $\begin{array}{l}\text { Turn object } \\
\text { classification } \\
\text { properties } \\
\text { into 'To Be } \\
\text { Demolished' } \\
\text { or 'New' from } \\
\text { 'Existing' }\end{array}$ \\
\hline
\end{tabular}




\section{Conclusion}

Based on the explanation above, it can be concluded that BIM and Renovation Tools on study objects with larger buildings will more efficient in their depiction work, while on smaller study objects the efficiency level remains the same as 2D CAD, but BIM has other advantages such as collison of two building components on one point and automatic work volume calculation which is not the subject of this writing.

\section{Acknowledgment}

I thank to my colleagues Mr. Novan Prayoga and all member of NFN Studio who provided insight and expertise that greatly assisted the research, although they may not agree with all of the interpretations/conclusions of this paper.

\section{References}

Berlian, Cinthia Ayu, dkk. (2016). Perbandingan Efisiensi Waktu, Biaya Dan Sumber Daya Manusia Ántara Metode Building Information Modelling (Bim) Dan Konvensional (Studi Kasus: Perencanaan Gedung 20 Lantai). Jurnal Karya Teknik Sipil Universitas Diponegoro, Volume 5, Nomor 2, Tahun 2016, Halaman $220-229$

Dace, A. C. (2007). Building Information Modeling : the Web 3d Application for AEC. Perugia, ACM, Italy.

Helander, David and Singh, Vishal. (2016). BIM in Building Renovation Projects : What is the useful minimum information requirement? International Journal, Product Lifecycle Management. Vol. 9, No. 1, 2016, p 65-86.

Minawati, Retno, dkk. (2017). Manfaat Penggunaan Software Tekla Building Information Modeling (Bim) Pada Proyek Design-Build. Jurnal Dimensi Utama Teknik Sipil Universitas Petra Surabaya, Volume 4, Nomor 2, Tahun 2017.

Rayendra, Soemardi, Biemo W. (2014). Simposium Nasional RAPI XIII - 2014 FT UMS, ISSN 1412 9612. 